\title{
Recenzja książki Wojciecha Lamentowicza, Strategia państwa: teoria państwa aktywnego wobec siłspontanicznych, Dom Wydawniczy ELIPSA, Warszawa 2015, ss. 258
}

I. Prezentacja książki pt. Strategia państwa: Teoria państwa aktywnego wobec sił spontanicznych moim zdaniem w pierwszej kolejności wymaga przedstawienia jej autora. Każdy, kto miał zaszczyt osobistego poznania Profesora Wojciecha Lamentowicza, a tym bardziej wysłuchania jego wystąpień, po lekturze tej książki niewątpliwie jeszcze raz przekona się, jak znamienitym jest on naukowcem, jak bardzo wnikliwym obserwatorem otaczającej nas rzeczywistości, z jaką lekkością myśli i świeżością spojrzenia potrafi przedstawić zjawiska współczesnego świata, tak że stają się bardziej czytelne nawet dla osób mniej zorientowanych w życiu społecznym politycznym czy gospodarczym.

Profesor Wojciech Lamentowicz to znamienity polski prawnik (nie tylko teoretyk, ale również praktyk), polityk i dyplomata (były ambasador Rzeczypospolitej Polskiej w Grecji i na Cyprze), poseł na Sejm II kadencji, wykładowca i członek władz uczelni polskich i zagranicznych, członek Polskiej Akademii Nauk, specjalista z zakresu teorii państwa i prawa, filozofii prawa oraz prawa międzynarodowego. Lektura jego publikacji, w tym niniejszej książki, nasuwa refleksję o odwadze i konsekwencji w prezentowaniu analizy zjawisk współczesnego świata, jak również rzadko spotykanej umiejętności ich przekazu przeciętnemu czytelnikowi.

II. Prezentowana książka, jak zaznacza we wstępie sam autor, ma stanowić swego rodzaju kompilację jego poglądów i rozważań „o państwie aktywnym wobec żywiołowości zmian i zarazem głównym aktorze strategicznym w systemie globalnym" (s. 9), które do tej pory były rozwijane w jego twórczości i zajmują istotne miejsce w jego dorobku naukowym. Przewodnim tematem jest problematyka dotycząca istoty i roli współczesnego państwa, w szczególności państwa funkcjonującego w reżimie demokratycznym, napotykającego na różnego rodzaju trudności natury politycznej, społecznej czy gospodarczej i usiłującego sobie z nimi poradzić, przezwyciężyć je albo przynajmniej zminimalizować. Lektura recenzowanej książki prowadzi do 
wniosku, iż takim narzędziem, mogącym odegrać istotną rolę w walce państwa i jego władz z rozmaitymi problemami, jest wykorzystanie tzw. wielkiej strategii. Autor chciałby tym samym „zwiększyć zainteresowanie różnych kręgów społecznych problematyką metodologiczną związaną z tworzeniem i realizacją wielkich strategii na poziomie elit władzy państwa współczesnego w systemie globalnym, gdzie spotykają się, co najmniej, trzy światy przednowoczesny, nowoczesny i ponowoczesny. Bez sztuki tworzenia wielkich strategii i ich implementacji zmarnuje się regulacyjny i innowacyjny potencjał państwa"1 (s. 9).

Praca ma charakter interdyscyplinarny, autor korzysta bowiem nie tylko $\mathrm{z}$ dorobku nauk prawnych, których zresztą jest wybitnym przedstawicielem, ale sięga również do opracowań z nauk o polityce, nauk historycznych, ekonomicznych, nauk o wojskowości, nauk o stosunkach międzynarodowych czy socjologii. Zastosowana w ten sposób metoda badawcza pozwala na wszechstronne, wielopłaszczyznowe zaprezentowanie tematu.

III. Książka składa się z dziewięciu rozdziałów. Dwa pierwsze mają charakter wprowadzający do analizy zagadnień zawartych w kolejnych częściach. Poświęcone zostały precyzyjnemu wyjaśnieniu podstawowych pojęć stosowanych przez autora w kolejnych rozdziałach, zdaje on sobie bowiem sprawę $\mathrm{z}$ tego, że „w holistycznej i trans-dyscyplinarnej nauce o strategiach bardzo wiele pojęć ma liczne znaczenia i jeszcze liczniejsze definicje. W takiej sytuacji trzeba przyjąć któreś z istniejących znaczeń albo zaproponować własne definicje regulujące i konsekwentnie posługiwać się takimi sposobami rozumienia terminów podstawowych dla konkretnego projektu badawczego" (s. 15). Biorąc to pod uwagę, w rozdziale I, zatytułowanym „Pole myślenia strategicznego: podstawowe pojęcia”, Profesor Wojciech Lamentowicz przedstawia propozycje takich pojęć jak strategia, strategiczność czy tzw. wielka strategia państwa, wskazuje na kilka istotnych aspektów w pojęciu strategii, a mianowicie na jej wymiar praktyczny, celowościowy czy organizatorski, jak również opisuje relacje pomiędzy pojęciem strategii a pojęciem bezpieczeństwa. W tym miejscu warto zwrócić uwagę na wynikający z całokształtu rozważań autora pogląd, wedle którego nie należy pojęcia strategii, w tym strategii państwa, ograniczać jedynie do strategii bezpieczeństwa narodowego czy też bezpieczeństwa wewnętrznego. W ogólnie przyjętym znaczeniu strategia państwa powinna oznaczać ciąg przemyślanych decyzji kreujących zorganizowane działania celowe, tj. decyzji logicznie wiążących cele, sposoby i środki ich osiągania w praktycznym działaniu. Fundamentalnym motywem tak rozumianej strategii powinno być dążenie do formułowania działań celowych poszczególnych podmiotów, tak aby osiągały one wytyczone cele pomimo napotykanych trudności. W przypadku pojęcia strategii państwa istotne jest to, iż „ośrodek decyzji i koordynacji jest na najwyższym poziomie hierarchii władzy

1 Pisownia wszystkich cytatów oryginalna - przyp. red. 
państwa, a podstawą wyboru celów są najważniejsze interesy społeczeństwa żyjącego w ramach instytucjonalnych tego państwa takie jak sama egzystencja tej społeczności, jej bezpieczeństwo, tożsamość i szanse rozwoju” (s. 19). Tak rozumiane pojęcie strategii państwa nawiązuje do pojęcia tzw. wielkiej strategii (ang. Grand Strategy), które - jak to zostało wcześniej nadmienione - nie dotyczy tylko bezpieczeństwa narodowego, ale odnosi się również do innych, równie ważnych interesów państwa, takich jak ochrona jego egzystencji, tożsamości, niezależności czy szans rozwoju. W takim ujęciu Grand Strategy składa się ze strategii politycznych, ekonomicznych i militarnych.

Podsumowując rozważania na ten temat, autor stwierdza, że wielka strategia oznacza główne cele polityki państwa, jak też metody i środki ich osiągania (o charakterze długofalowym) zarówno na terenie państwa, jak i poza jego granicami, dotyczące egzystencjalnych, najważniejszych interesów państwa oraz zawierające w sobie - zależne od kultury i poziomu cywilizacyjnego - „wyobrażenie o racji stanu i pożądanej przyszłości tego państwa w zmieniającym się systemie międzynarodowym” (s. 27). Fundamentalnymi kategoriami strategicznego myślenia są:

1) podłoże historyczne- całokształt statycznych i niemożliwych do zmiany warunków uformowanych na przestrzeni czasu jako efekt procesów gospodarczych, politycznych, społecznych czy kulturowych. Jest to najbardziej stabilny element myślenia strategicznego, który jednak w pewnym sensie może ulec swoistej zmianie na skutek sposobu jego postrzegania, rozumienia i interpretacji;

2) aktorzy procesów strategicznych - osoby, grupy osób czy organizacje, których podmiotowość wyrasta $\mathrm{z}$ ich zdolności do uświadamiania sobie własnych interesów oraz umiejętności ich realizacji;

3) podłoże normatywne - to całokształt norm (prawnych, etycznych, organizacyjno-wojskowych itd.) regulujących zachowania aktorów procesów strategicznych. W tym miejscu warto zwrócić uwagę na pogląd autora dotyczący rygorystycznego przestrzegania norm - „tylko szaleńcy i ludzie emocjonalnie niezrównoważeni przestrzegają norm rygorystycznie. Racjonalni pragmatycy szukają luk w systemach normatywnych i maksymalizują luzy decyzyjne. Potrzebują zawsze swobody manewru i dążą do sytuacji o wielu możliwych wyjściach" (s. 40);

4) zgodnie z zasadą proporcjonalności - cel adekwatny do stosowanych środków oraz środki zdatne do osiągnięcia założonych celów;

5) zdarzenia strategiczne, będące przedmiotem procesów strategicznych - są to stany rzeczy (zdarzenia statyczne) i procesy (zdarzenia dynamiczne);

6) instytucje, tj. układy reguł zachowania, które służą agregacji interesów podmiotów oraz rozwiązywaniu konfliktów tych interesów; 
7) kontekst sytuacyjny - całokształt okoliczności, w których strategia powstaje i jest realizowana;

8) scena działań strategicznych, np. lokalna, regionalna czy globalna, to miejsce spotkań i wzajemnego oddziaływania aktorów zarówno historycznego, jak i sytuacyjnego kontekstu strategicznego;

9) czas (który dla strategii nie musi być linearny) i przestrzeń (lokalna, narodowa czy globalna) - jako fundamentalne kategorie myślenia strategicznego, o najbardziej dynamicznym charakterze spośród wszystkich innych kategorii, które zostały wcześniej wymienione.

W rozdziale II, noszącym tytuł „Państwo, jako aktor scen strategicznych", zostały zawarte rozważania na temat państwa jako jednego $\mathrm{z}$ aktywnych podmiotów procesów strategicznych. Zdaniem Profesora Lamentowicza państwo nie jest jedynym tego rodzaju podmiotem, ale $\mathrm{z}$ całą pewnością można stwierdzić, że jest podmiotem pierwotnym, podstawowym i najważniejszym, choćby na arenie międzynarodowej. Nie sposób nie zgodzić się z autorem, będącym wybitnym znawcą prawa i stosunków międzynarodowych, iż ze wszystkich uczestników sceny międzynarodowej państwo posiada największe predyspozycje do kreowania i realizacji działań strategicznych, bardziej niż organizacje międzynarodowe czy inne gremia będące przejawem pozarządowej inicjatywy międzynarodowej. $Z$ tego też względu rozważania dotyczące strategii zawarte w kolejnych częściach recenzowanej książki autor odnosi głównie do państwa, jednakże uwzględnia kontekst międzynarodowy i globalny, stąd w rozdziale II prezentuje własne poglądy na temat złożoności systemu globalnego, międzynarodowego oraz roli i funkcji państwa $\mathrm{w}$ tym systemie. Warto $\mathrm{w}$ tym miejscu zwrócić uwagę na przyjęte przez Profesora Lamentowicza rozumienie pojęcia państwa aktywnego, które w pewnym sensie determinuje rozważania na temat strategii państwa zawarte w kolejnych rozdziałach książki. Sięgając do dorobku nauk politycznych, autor umiejscawia koncepcje państwa aktywnego „między socjaldemokratycznym a socjalliberalnym wariantem reform społecznych zapoczątkowanych w XX wieku, jako Welfare State i (...) kontynuowanych w XXI wieku w rozmaitych wariantach" (s. 53). Państwo aktywne nie zakłada jego zdaniem ingerencji w każdą sferę życia ludzi, powinno jednakże gwarantować takie dobra jak postęp, wolność, bezpieczeństwo czy porządek - z tego powodu musi być zatem państwem silnym. Jednak, jak słusznie zauważa Profesor Lamentowicz, „państwo często było i nadal na ogół jest formą panowania nad ludźmi, a także zniewalania ich w określonym stopniu. (...) bowiem każdy porządek nawet najbardziej liberalny i demokratyczny jest ograniczeniem wolności indywidualnej" (s. 51), co stanowi swego rodzaju koszt zalet związanych $\mathrm{z}$ istnieniem i funkcjonowaniem państwa, takich jak strategiczność państwa, pełnienie funkcji adaptacyjnych, regulacyjnych i innowacyjnych czy przeciwdziałanie szeroko pojętej chaotyczności. 
W swoim spojrzeniu na istotę i funkcję współczesnego państwa autor proponuje przyjąć postawę „złotego środka” i krytykuje skrajne poglądy niedoceniające albo przeceniające znaczenie i rolę państwa. Postulujew opozycji do tych skrajnych poglądów- dostrzeganie i branie pod uwage zarówno wad, jak i zalet państwa. Przykładowo państwo może być dobrym sposobem rozumnego zorganizowania wolności, ale z drugiej strony jest bytem dotkniętym różnego rodzaju patologiami, jak biurokracja, tendencja do oligarchizacji władzy publicznej, korupcja władzy publicznej przez własność prywatną czy autorytarna alienacja elit rządzących. Profesor Lamentowicz prezentuje zatem, jak sam ją nazywa, postawę umiarkowanego optymizmu dotyczącego strategicznych zdolności państwa i pokazuje, jak radzi sobie ono w roli twórcy i realizatora strategii wielkich i sektorowych. Jego zdaniem prawidłowo zorganizowane demokratyczne państwo prawa może stanowić przykład racjonalnego ładu wyrastającego z połączenia takich fundamentalnych jego wartości, jak wolność, sprawiedliwość, równość i bezpieczeństwo. Natomiast państwo jako aktor procesów strategicznych powinno cechować się faktyczną niezależnością i skuteczną sprawczością, opartą na odpowiednim używaniu zasobów i środków. „Sam aktywny udział konkretnego państwa w rozwiązywaniu problemów globalnych i regionalnych jest oczywiście bardzo ważny. Ale jeszcze ważniejszy jest realny wpływ na treść decyzji kluczowych dla trwania i rozwoju systemu globalnego" (s. 10).

IV. Pozostałe rozdziały recenzowanej książki (III-IX) poświęcone zostały poszczególnym aspektom związanym $\mathrm{z}$ formułowaniem i realizacją strategii państwa.

Rozdział III stanowi swego rodzaju vademecum w zakresie tworzenia i realizacji strategii, na kształt podręczników strategicznego myślenia i działania, jakimi posługują się rządy czy też siły zbrojne poszczególnych państw. W procesie tym Profesor Wojciech Lamentowicz wyróżnia cztery etapy:

- etap rozpoznania,

- etap selekcyjny,

- etap realizacyjny,

- etap ewaluacyjny.

Na każdym z etapów mamy do czynienia z odpowiednim podziałem ról, działań i wskazaniem głównych podmiotów, które je wykonują. Natomiast szczegółowa prezentacja czynności podejmowanych w poszczególnych etapach została zawarta przez w kolejnych rozdziałach pracy - od IV do IX.

W tym miejscu warto jeszcze zatrzymać się nad przeprowadzoną w rozdziale III analizą różnorodnych przesłanek wyboru strategii. Autor wyróżnił mianowicie obiektywne i subiektywne przesłanki wyboru. Do pierwszej kategorii zaliczył szereg uwarunkowań, które są niezależne od woli i rozumu strategów, a mianowicie instytucjonalne podstawy strategii, typy 
strategii, pozycję państwa w hierarchii potęgi państw, witalność cywilizacyjną społeczeństwa i jego kultury, role pełnione przez państwo w środowisku międzynarodowym, lokalizację geograficzną i kulturową państwa, wielkość różnicy potencjałów państw, stopień podzielności dóbr spornych między państwami, poziom i jakość aktualnej legitymizacji pozycji i strategii aktorów. Natomiast wśród tzw. subiektywnych, czyli psychologicznych przesłanek wyboru strategicznego, można znaleźć: myślenie kreatywne i analityczno-krytyczne, strategiczne umiejętności przywódców (a w szczególności ich wiedzę, wiarę w sukces, nadzieje i lęki), rodzaj i siłę wewnętrznych motywacji, typy moralnych zobowiązań uznawanych przez aktorów lub dominujących w danej kulturze, wyobrażenie o tworzeniu strategii, a nawet emocje, złudzenia czy intuicję.

V. Rozdziały IV i V książki poświęcone zostały szczegółowemu opisowi działań podejmowanych w pierwszym etapie procesu tworzenia i realizacji strategii, a mianowicie wyjaśnieniu przeszłości i analizie kontekstu fundamentalnego.

Zaproponowana przez autora metodologia przygotowania strategii państwa przyjmuje, iż koniecznym, wręcz niezbędnym działaniem, niejako inicjującym ten proces, jest analiza podłoża historycznego, czyli wyjaśnienie przeszłości - działanie to w dużej mierze determinuje kolejne kroki podejmowane $\mathrm{w}$ procesie tworzenia strategii, przy czym w zależności od założonych celów i problemów przyjętych do rozwiązania, głębokość i rodzaj analizy podłoża historycznego mogą być one różne. $Z$ tego też powodu autor proponuje odpowiednie stosowanie takich rodzajów wyjaśnień, jak wyjaśnienia przyczynowe (deterministyczne) i wyjaśnienia niedeterministyczne.

Drugą kluczową czynnością w procesie tworzenia strategii jest analiza sytuacji obecnej, teraźniejszości. W jej ramach dokonuje się swego rodzaju rozpoznania pola przyszłego działania, a w szczególności ustalenia rodzaju problemów (czy są to zagrożenia, wyzwania czy szanse). Należy odpowiedzieć na pytanie, czy w danym przypadku możliwe jest przyjęcie jednego czy kilku rozwiązań, a może jest to raczej sytuacja bez wyjścia, czy mamy do czynienia z pojedynczym problemem, czy też raczej z tzw. kategorią nierozwiązywanych problemów szczególnie trudnych (problemy złośliwe, węzły gordyjskie i błędne koła okrężnej przyczynowości itd.)? W tym miejscu warto zwrócić uwagę na wydawałoby się oczywistą i często występującą sytuację, na którą wskazuje autor, a mianowicie fakt, że „sploty problemów (np. problemy niesforne i złośliwe, węzły gordyjskie, błędne koła, wąskie gardła) są w praktyce znacznie częstsze niż problemy pojedyncze” (s. 133).

Etap rozpoznania, jak słusznie zauważa Profesor Wojciech Lamentowicz, nie ogranicza się jedynie do wyjaśnienia przeszłości i analizy sytuacji obecnej, ale obejmuje również prognozowanie, czyli przewidywanie przyszłości przy użyciu rozmaitych metod racjonalnego i krytycznego myśle- 
nia, jak też przy wykorzystaniu możliwie najdokładniejszej wiedzy uzyskanej z analizy przeszłości i teraźniejszości. Oprócz metod prognozowania strategicznego, co istotne dla nie tylko dla celów poznawczych, ale również pragmatycznych, autor wskazuje wcześniejsze historycznie sposoby myślenia o przyszłości (ignorancja, proroctwa, przepowiednie, wyobrażenia lub wizje czy przeczucia oparte na intuicji lub empatii, myślenie życzeniowe), jak również przesłanki i źródła błędów w prognozowaniu.

VI. Kolejny etap procesu tworzenia i implementacji strategii to etap selekcyjny. Najistotniejsze zagadnienia związane z jego przebiegiem zostały opisane w rozdziale VI, zatytułowanym „Czas i przestrzeń w myśleniu strategicznym”. Jak słusznie zauważa autor, jest to jeden $\mathrm{z}$ istotniejszych fragmentów analizowanego procesu, wiążący się z dokonywaniem fundamentalnych wyborów, przesądzających właściwie o kształcie strategii, jej przebiegu czy nawet o jej granicach. Na tym etapie podmiot decyzyjny ustala tak ważne kwestie, jak ramy czasowe, moment rozpoczęcia strategii, jak również poszczególnych jej etapów. Niezwykle ważnym wyborem jest ponadto ustalenie celu, czy też celów, które mają zostać osiągnięte, wyznaczenie swego rodzaju hierarchii celów - „należy wybrać i opisać cele pożądane i osiągalne oraz uporząakować je w jakiś sposób” (s. 83), podstawowych zasad dążenia do osiągnięcia pożądanego stanu rzeczy.

$\mathrm{W}$ analizowanym rozdziale można spotkać niezwykle interesujące rozważania nad istotą czasu w procesie strategicznym. Na wstępie autor przywołuje filozoficzne poglądy (prezentyzm, posybilizm, eternalizm) dotyczące czasu, a w szczególności kwestii teraźniejszości, przeszłości i przyszłości. Następnie bierze pod uwagę szereg wypadkowych, które mogą wpłynąć na postrzeganie czasu - okazuje się, że wbrew pozorom czas stosunkowo często nie stanowi jednolitego procesu o równym, niezmiennym tempie. Zjawiska i zdarzenia nieprzewidywalne (tzw. czarne łabędzie), brak proporcji między przyczynami i skutkami (np. tzw. efekt motyla), rosnące tempo zmian w społeczeństwie sprawiają, że czas bardzo często „nie jest (...) zdarzeniem, obiektem czy pasmem obiektów, lecz raczej tym co oddziela od siebie przyczyny i skutki, nie będąc zarazem substancjonalną granicą o fizycznym charakterze. (...) Czas jest więc raczej podobny do nieuregulowanej rzeki górskiej niż do wody płynącej wąskim kanałem o wyrównanych brzegach. Jest pasmem poszarpanym na segmenty o rozmaitych cechach specyficznych i nie jest rozumnie zakładać, że czas jest ostoją regularności w rzeczywistości pełnej nieregularnych zdarzeń, nieliniowych relacji i skokowych zmian sytuacji” (s. 156-159).To wszystko sprawia, że myślenie strategiczne jest niezwykle trudną umiejętnością i stanowi istotne wyzwanie dla wielu decydentów strategicznych.

Oprócz tych filozoficznych rozmyślań nad naturą czasu w rozdziale VI można spotkać istotne dla myślenia strategicznego determinanty. Profesor Lamentowicz wymienia ważne kwestie, o których istnieniu powinien pa- 
miętać strateg. W tym zakresie powinny zatem pojawić się pytania na temat skończoności czy też nieskończoności czasu, tego, w jakiej kulturze czy też kulturach jest zanurzony czas społeczny, jak i dla kogo upływa czas.

VII. W kolejnej części recenzowanej książki możemy spotkać się z niedocenianym - jak twierdzi autor - w Polsce czy w innych państwach na zachód od Odry zagadnieniem kultury strategicznej w państwie. Pojęcie to pojawiło się już w latach 70 . XX w. w analizach strategicznych i w teorii stosunków międzynarodowych Zachodu i ulegało z upływem czasu swoistej ewolucji. Biorąc pod uwagę szereg koncepcji dotyczących tego pojęcia, autor proponuje własną definicję o uniwersalnym charakterze. Jego zdaniem „kultura strategiczna to społecznie przekazywane, wynikające z tożsamości i głównego nurtu kultury politycznej danego społeczeństwa idee, wartości, normy, rodzaje wiedzy, postawy i wzory zachowania dotyczące rozumienia bezpieczeństwa narodowego i międzynarodowego, a zwłaszcza celów, zakresu i sposobów używania siły zbrojnej i innych rodzajów siły w stosunkach międzynarodowych" (s. 190). W dalszej części mamy do czynienia z niezwykle interesującą i wnikliwą analizą postrzegania kultury strategicznej przez USA i na kontynencie europejskim, w szczególności w ramach państw i społeczeństw Unii Europejskiej.

VIII. Jednym z najbardziej interesujących zagadnień poruszonych przez autora w niniejszej pracy (rozdział VIII) jest problematyka tzw. efektu tsunami. Jest to swego rodzaju sytuacja bez wyjścia lub w najlepszym wypadku sytuacja o jednym wyjściu, która utrudnia, a nawet może uniemożliwić myślenie i działanie strategiczne. Zagadnienie to jest niezwykle aktualne, na co wskazują wydarzenia kilku ostatnich lat, takie jak choćby kryzys gospodarczy, kryzys migracyjny itd. Te wydawałoby się sytuacje bez wyjścia powinny jednak stanowić wyzwanie dla strategów. Autor już we wstępie zakłada, iż w podobnej sytuacji należy raczej być tzw. „tragicznym optymistą: widząc z całą ostrością sploty nierozwiązywanych problemów szczególnie trudnych (problemy złośliwe, węzły gordyjskie i błędne koła okrężnej przyczynowości), głęboko zakorzenionych i wzajemnie splątanych ukrytymi pod ziemią kłączami (...) rozumiem, że należy nieustannie szukać nadziei na ich rozwiązywanie. (...) Tragiczny optymizm nie jest naiwny i nie daje łatwo wiary ani pesymistom wieszczącym zmierzch naszej cywilizacji, ani naiwnym optymistom, którzy sądzą, że przyszłość to zawsze pozytywne rozwinięcie wszystkich potencjałów wytworzonych dotychczas. Jego podstawą jest bardzo krytyczna diagnoza stanu obecnego i silne dążenie do jego poprawy rozumnymi i ewolucyjnymi sposobami w granicach ustrojowych liberalno-demokratycznego państwa prawa” (s. 12).

IX. Finalny rozdział książki autorstwa Wojciecha Lamentowicza stanowi rozwinięcie kwestii związanych z ostatnim wymienionym przez niego etapem procesu strategicznego, a mianowicie etapem ewaluacyjnym. $\mathrm{W}$ odniesieniu do tego etapu procesu strategicznego autor proponuje 
i szczegółowo opisuje kryteria oceny strategii państwa relewantne w nauce o stosunkach międzynarodowych i ogólnej teorii państwa, dokonuje prezentacji nauk ewaluacyjnych i ich znaczenia $\mathrm{w}$ ocenie strategii państw, a także formułuje swego rodzaju wskazówki i rekomendacje pozwalające na doskonalenie myślenia i działania strategicznego.

Podsumowując analizę rozważań zawartych w książce Profesora Wojciecha Lamentowicza, można bezsprzecznie powiedzieć, że stanowi ona wyzwanie intelektualne. $Z$ drugiej strony jest to rzadko spotykany przykład literatury naukowej, którą czyta się jednym tchem, co chwilę uświadamiając sobie, jak trafnie i przejrzyście autor przedstawia - często trudne do wyjaśnienia i zrozumienia -zagadnienia współczesnego świata.

We wstępie do książki Profesor Lamentowicz sam przyznaje, że stanowi ona intelektualne zaproszenie. Po lekturze z całą pewnością polecam skorzystanie z tego zaproszenia każdemu, kto pragnie przeżyć niezwykłą intelektualną przygodę. 